Healing the Masses 



\title{
Healing the Masses
}

Cuban Health Politics at Home and Abroad

\author{
Julie Margot Feinsilver
}

with a Foreword by David E. Apter

UNIVERSITY OF CALIFORNIA PRESS

Berkeley / Los Angeles / London 
University of California Press

Berkeley and Los Angeles, California

University of California Press, Ltd.

London, England

(C) 1993 by

The Regents of the University of California

\section{Library of Congress Cataloging-in-Publication Data}

Feinsilver, Julie Margot.

Healing the masses : Cuban health politics at home and abroad / Julie Margot Feinsilver.

p. $\mathbf{c m}$.

Includes bibliographical references and index.

ISBN 0-520-08218-4 (alk. paper). - ISBN 0-520-08298-2

(pbk. : alk. paper)

1. Medical policy-Cuba. 2. Medical care-Political aspectsCuba. 3. Medical assistance, Cuban-Political aspects.

4. Symbolism in politics-Cuba. I. Title.

RA395.C9F45 1993

362.1'097291-dc20

$92-31124$

Printed in the United States of America

CIP

$\begin{array}{lllllllll}9 & 8 & 7 & 6 & 5 & 4 & 3 & 2 & 1\end{array}$

The paper used in this publication meets the minimum requirements of American National Standard for Information Sciences-Permanence of Paper for Printed Library Materials, ANSI Z39.48-1984. 
To the memory of Ethel Marcus Feinsilver and to

Jacob Monroe Feinsilver 
